\title{
SUB-SAHARAN AFRICA'S RAIL FREIGHT TRANSPORT SYSTEM: POTENTIAL IMPACT OF DENSIFICATION ON COST
}

\author{
ANNEKE DE BOD \\ JAN HAVENGA \\ janh@sun.ac.za \\ Centre for Supply Chain Management, Department of Logistics \\ Stellenbosch University \\ South Africa
}

\begin{abstract}
The main response to sub-Saharan Africa's (SSA) challenges has been foreign aid. Yet, despite the large amounts received, the challenges remain. There is an opportunity to consider a different model with less focus on aid and more on investment. In the transport sector specifically, investment decisions should be informed by a longterm optimal balance between different transport modes. The research presented in this paper highlights the significant cost reduction opportunities possible through the densification of rail freight, especially over longer distances, with concomitant implications for increased profitability for rail operators. The densification opportunity should also place a core focus on transport corridors being developed throughout the region. SSA countries themselves can play a critical role in unlocking this potential through, inter alia, simplifying regional economic communities and taking the lead in structuring agreements with the international community.
\end{abstract}

\section{INTRODUCTION}

Sub-Saharan Africa's (SSA) economic growth slowed down to $1 \%$ in 2009 due to the global recession, but expectations are that growth will quickly recover to the $5 \%$ that was recorded for most of the past decade (IMF, 2009). The International Monetary Fund (IMF) expects growth in SSA to rise to $4 \%$ in 2010 and 5\% in 2011. The historical growth performance and expectations are based on internal improvements such as prudent macroeconomic management and external improvements such as debt relief and strong global demand for commodities, which have helped increase resources and boost growth. As has been well documented, there are, however, still numerous challenges facing the region, from basic human needs to capacity for innovation (Madavo, 2005; Taylor, 2006; Moyo, 2009). The key challenges of relevance in this paper are highlighted below.

First, the region's poor global ranking in terms of property rights and freedom from corruption is indicative of the remaining governance challenges. Addressing these challenges is one of the keys to unlocking an environment that would allow a virtuous cycle of entrepreneurship, innovation, investment, and sustained economic growth and development to flourish (Holmes, Feulner \& O'Grady, 2008). 
Secondly, although all the Regional Economic Communities (RECs) recognise the importance of improving trade facilitation to foster economic growth and poverty eradication, the complex web of regional integration agreements in Africa (as depicted in Figure 1) leads to inefficiency (Ndulu, Kritzinger-van Niekerk \& Reinikka, 2005: 117).

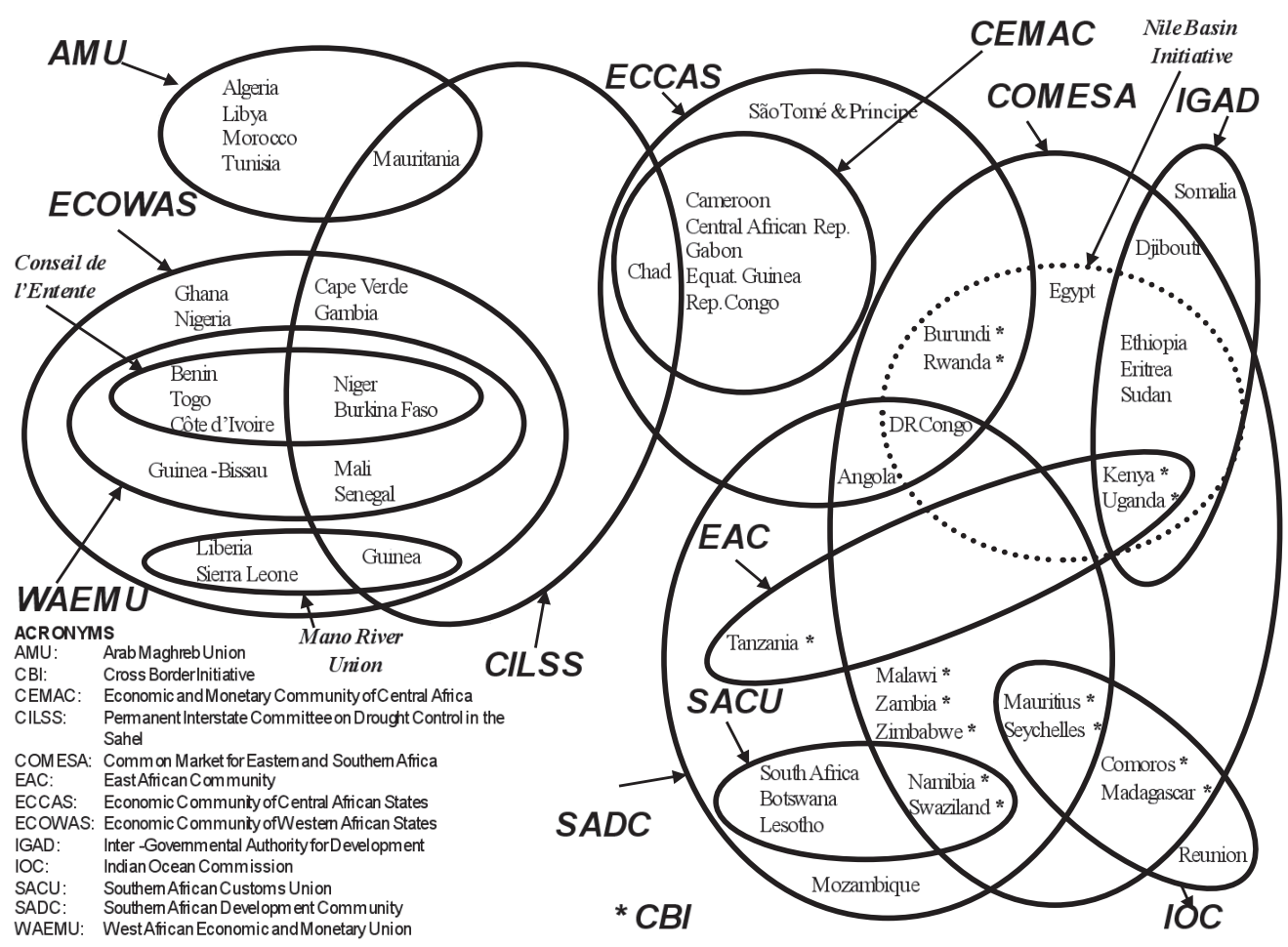

Figure 1: Complex regional integration agreements in Africa (Ndulu et al., 2005)

Thirdly, heavy dependence on primary commodity exports remains a common feature of most countries in SSA. This exposes the sub-region to external shocks and makes economic diversification a top priority for growth policies on the continent (UNECA, 2007).

Finally, SSA's transport-related infrastructure is limited, generally in a poor condition, and operating below design capacity, impeding development. Cross-border corridor transport in most of SSA is costly, slow and unreliable. This exacerbates transport challenges for landlocked countries in SSA with export potential (De Bod, 2008).

The main response to these challenges has been increasingly ambitious programmes of foreign aid (Easterly, 2008). With just a fraction of the population of Asia, SSA receives more foreign aid, both multilateral and bilateral, than any other region (Holmes et al., 2008). Since the 1940s, more than US\$1 trillion has been sent to Africa. However, between 1970 and 1998, when aid flows to Africa were at their peak, poverty in Africa rose from $11 \%$ to a staggering 66\% (Moyo, 2009). Challenges with foreign aid have been highlighted as far back as 1972 by Peter Bauer. Bauer's key criticisms were that aid was being targeted at inappropriate investments and therefore resulting in the misallocation of scarce resources. Over time, the temptation of corruption and kickbacks to donor countries further exacerbated this situation (Shleifer, 2009). 
There is increasing debate regarding the effectiveness of foreign aid (see, for example, Chowdhury \& Garonna, 2007; Easterly, 2008; Moyo, 2009). Alternative approaches are continuously proposed. Moyo is in favour of an approach where African nations take charge of their own growth by learning to tap into international financial markets by encouraging foreign investment (Clendaniel, 2009), while China is granting resource-backed loans which seem to result in the building of much-needed infrastructure (Brautigam, 2010). Chowdhury and Garonna (2007) reiterate the importance of 'political thrust, strategic purpose, institutional support, bold reform initiatives' and successful integration into the global economic system. Easterly (2008) warns against continuous fallback on 'big-push' transformational aid programmes, and suggests that there is more evidence of the success of small, targeted interventions in Africa.

Yet, while the debate continues on the many approaches to addressing SSA's development challenges, the fact remains that for SSA to achieve the 7\% GDP growth rates needed to reduce poverty, infrastructure investment requirements amount to around US $\$ 20$ billion per year, twice as much as the region invested historically (World Bank, 2005). Providing reliable, effective and efficient freight transport infrastructure is a key component of this investment (Njini, 2010).

Research prepared by the Organisation for Economic Co-operation and Development (OECD) (Santiso, 2006) confirms the need for this focused investment as transport cost in SSA is considerably higher than elsewhere in the world, severely hampering the competitiveness of the region. A comparison between transport and insurance costs as a percentage of trade value for the OECD, developing countries and SSA is illustrated in Figure 2.

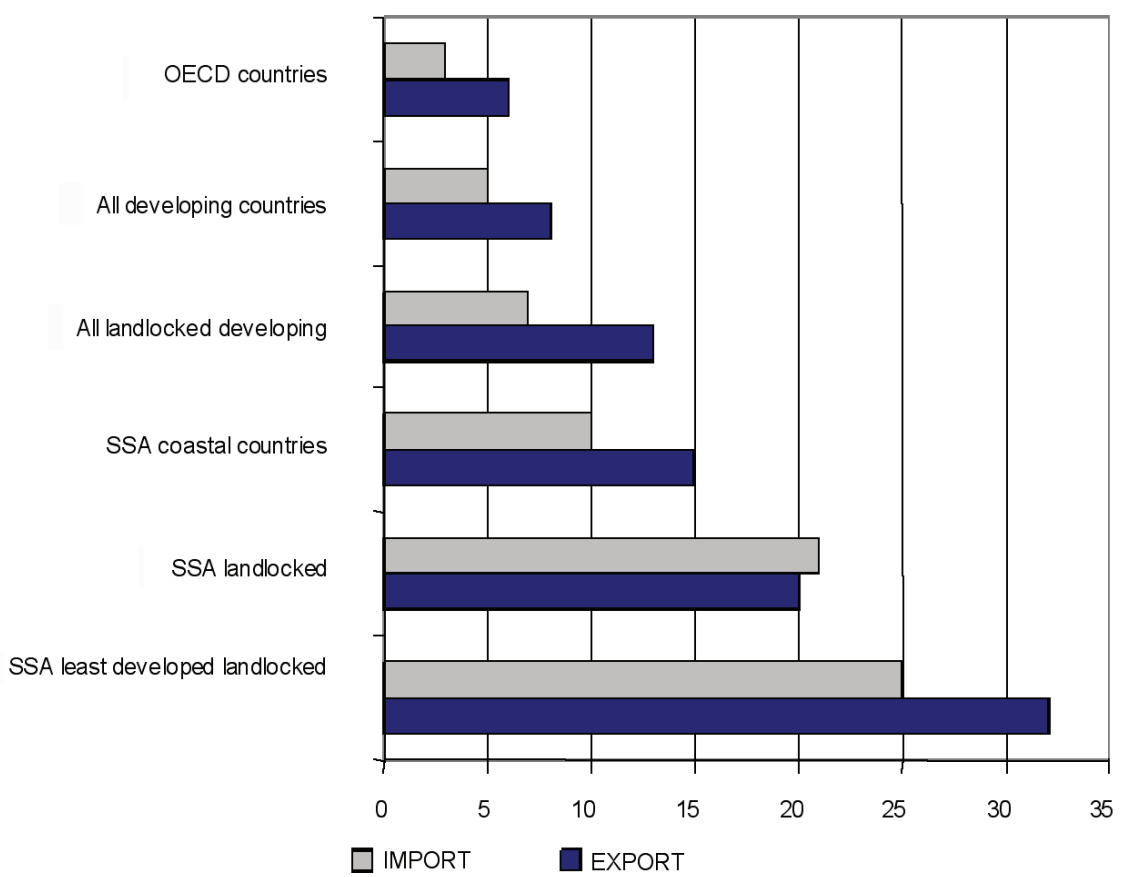

Figure 2: Transport and insurance costs as a percentage of trade value (Santiso, 2006) 
A study conducted by the World Bank (2006) on SSA railway concessions highlighted that rail still offers the most cost-effective solution to transporting non-time-sensitive bulk freight on distances over 500 km. Havenga (2007), Pittman (2007) and Drew (2006), among others, however highlight the importance of density to leverage rail's cost-effectiveness over longer distances due to rail's high fixed infrastructure component. The density of railroads in Africa has however decreased since the 1970s due to the increasing shift of freight traffic from rail transport to road transport (Simuyemba, 2007). In the context of freight rail transport, economies of density describe the relationship between inputs and outputs with a fixed rail network (Graham, Couto, Adeney \& Glaister, 2003), or the phenomenon that an 'increase in traffic over a given infrastructure will be met by a less than proportionate increase in costs' (Joy, 1989).

The objective of this paper is to illustrate the potential to reverse this trend due to the considerable economies of density attainable in rail freight transport in SSA, which could form the backbone of more targeted investment planning on the subcontinent. At the outset, the impact of density economies on rail freight transport is discussed. This is followed by a summary of the research approach, a discussion of the research results and concluding remarks.

\section{THE IMPACT OF DENSITY ECONOMIES ON RAIL FREIGHT TRANSPORT}

In 1977, Robert G. Harris wrote a seminal paper (Harris, 1977) stating:

The extent of economies of traffic density in the rail freight industry is a matter of critical importance with respect to public investment in and the financial viability of the United States of America (USA) rail system. The evidence strongly supports the hypothesis that significant economies of density exist, and that many of the lightdensity lines, which comprise $40 \%$ of the rail system, should be eliminated.

Rail invests in assets with useful lives measured in decades; asset-driven fixed costs (a significant proportion of total costs) can therefore not be reduced rapidly in the event of traffic loss. Due to this high level of fixed costs, the average cost per ton-kilometre and profitability are directly related to the degree of traffic density, i.e. the volume of traffic per kilometre of railroad, expressed as ton-kilometre per route-kilometre (ton-km/route-km). This means that the cent per ton-km cost of a railroad will decrease with each additional ton-km activity over the same track length. This relationship is illustrated in Figure 3. 


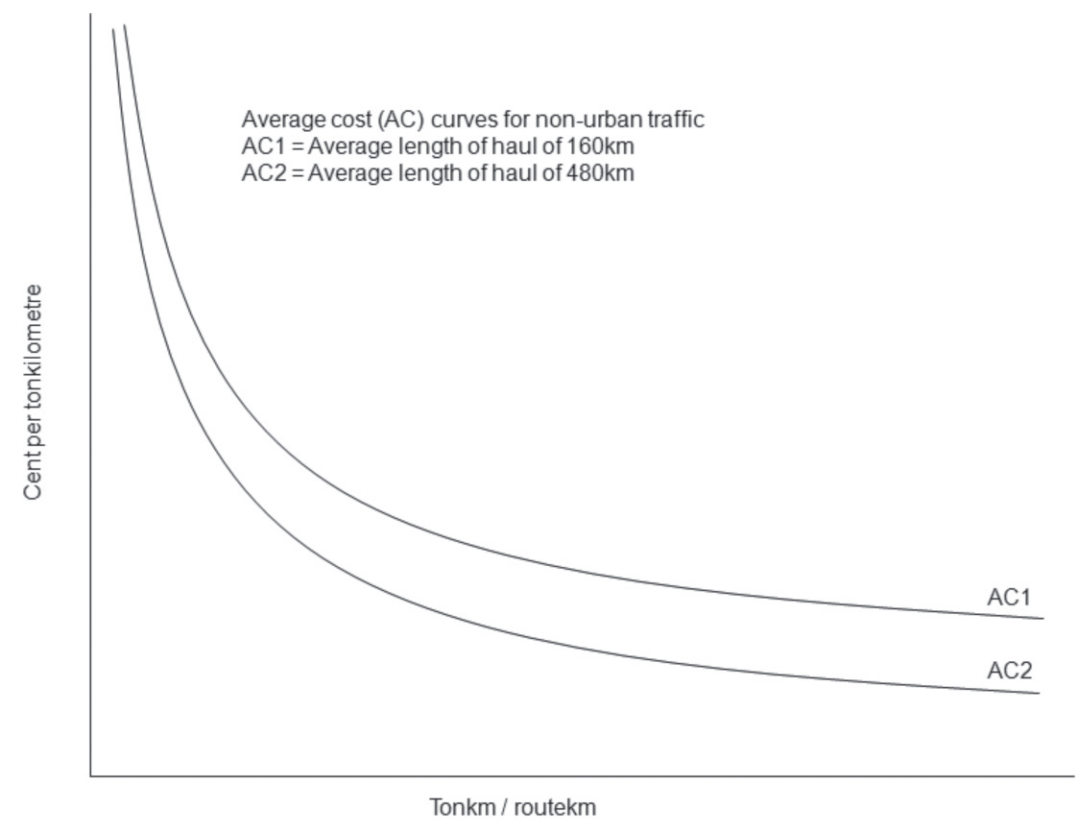

Figure 3: Stylised depiction of Harris's curve - Impact of density on rail costs (Harris, 1977)

A recent study conducted by Mercer on Class I and regional railroads in the USA in 2002 confirmed this curve. The study also emphasised that adequate traffic density is essential to meet the efficiency levels required to be competitive and to provide the economic returns necessary to justify investment (Mercer, 2002).

The challenges brought about by loss of density economies for a freight railroad were highlighted as a result of the continuous vertical separation debate among policy makers (see, for example, Ivaldi \& McCullough, 2001; Drew, 2006; Pittman, 2007). Vertical separation is the 'splitting of the vertically integrated railway into two independent enterprises, one controlling the infrastructure and the other operating trains' to increase competition (Pittman, 2007).

In a case study of the impact of vertical separation during rail privatisation in Great Britain, Drew (2006) concludes that costs for the railways as a whole increased while operating performance declined, despite an increase in rail ton- $\mathrm{km}$ market share following privatisation from $8.5 \%$ to $11.5 \%$. Competition between the privatised rail entities resulted in an inability to charge tariffs to cover fixed costs. As a result the rail freight industry is not sufficiently profitable to provide a normal return on capital invested.

Pittman (2007) shows that econometric studies by and large show that existing freight railways are operating at levels where there are still economies of density to be achieved. The primary caution against vertical separation is therefore the concern that competing operators would be unable to reach the available economies of density in rail freight hauling due to fragmentation. 


\section{RESEARCH APPROACH}

The focus of this paper is on all SSA countries, excluding South Africa. South Africa's transport challenges and opportunities have been well documented (refer to, inter alia, Havenga [2007] and the annual State of Logistics Survey, CSIR and Stellenbosch University [2009]). The principle of density analysis has been applied to the South African system, but is not the main focus of this article. The position of development funding and how it is obtained are different for most countries other than South Africa - and is the main focus of this article. However, a concise overview of South Africa's freight demand model is provided here as it formed the basis of the freight-flow modelling approach for other SSA countries. The model has been validated and is applicable to other SSA countries because of the universality of Harris' density work, the fact that countries in SSA share the same rail gauge and concomitant transport geographical challenges.

A freight demand model for South Africa was developed in 2006 (and is updated annually) to establish a database for all South African freight flows as input for long-term infrastructure planning (Havenga, 2007). The modelling of total freight flows is based on gravity modelling of the supply and demand for 354 magisterial districts and 64 commodity groups. Actual rail freight data is subtracted from the total modelled flows, resulting in a comprehensive view of road freight transport.

For the research presented in this paper, freight flows for Botswana and Zambia were researched in actuality in the two countries, and gaps were modelled on similar principles as the South African freight demand model (although at a more consolidated level due to the lack of detailed data). Due to monetary constraints, this approach was not possible for all the countries in SSA. Due to the onerous task of gathering the detailed information discussed below, the sample was further limited to Southern African Development Community (SADC) countries, although the principles will be applicable to SSA. The extension of the model to other countries into SSA is important due to the economic interrelationship of the region and the SADC focus on development funding. By using indicators such as population, GDP and trade, an estimate of freight flows in the other countries is possible. Network length is also available, which enables the estimation of potential density. An important area for further research is the extension of freight demand modelling (not estimates by proxy) to other countries in the subcontinent.

To enable freight-flow analysis for the SADC countries (including South Africa, Botswana and Zambia), the following economic factors were researched:

- GDP and population statistics

- industry sector distribution patterns per country

- preferred modes of transport used

- installed and usable infrastructure for different modes - route-km and road quality index 
- spatial indices per country (size of country, coastal development and metropolitan placement)

- company sizes per industry.

Through a comparative analysis of the known freight flow volumes (for South Africa, Botswana and Zambia) and these economic factors, the freight flows for the remaining SADC countries were modelled. This model provides the only known view of actual and potential rail densities for SADC countries.

The modelled results are then compared to established international research (Harris, 1977; Ordover \& Pittman, 1994; Mercer, 2002; Pietrantonio \& Pelkmans, 2004) that compares ton-km with route-km in order to illustrate the impact of the potential density on rail costs in the various countries, which in turn impacts on the profitability of both the railways and the freight transported. The importance of the potential density in terms of the focus on corridor development is then highlighted.

\section{DISCUSSION}

The road and rail ton-km estimate, and the network length required to deliver this transport output is summarised in Table I.

Table I: SSA rail and road ton-km and network length (De Bod, 2008)

(Based on 2006 values which were the only consistent available data for all countries)

\begin{tabular}{|l|c|c|c|c|c|c|c|c|}
\hline Country & $\begin{array}{c}\text { Total tons } \\
\text { (million) }\end{array}$ & $\begin{array}{c}\text { Length of } \\
\text { rail }\end{array}$ & $\begin{array}{c}\text { Length of } \\
\text { road }\end{array}$ & $\begin{array}{c}\text { Length } \\
\text { of paved } \\
\text { road }\end{array}$ & $\begin{array}{c}\text { Rail } \\
\text { tons }\end{array}$ & $\begin{array}{c}\text { Road } \\
\text { tons }\end{array}$ & $\begin{array}{c}\text { Rail } \\
\text { ton-km }\end{array}$ & $\begin{array}{c}\text { Road } \\
\text { ton-km }\end{array}$ \\
\hline RSA & 731.0 & 20070 & 358596 & 59753 & 178.00 & 553.0 & 108000 & 170000 \\
\hline Kenya & 60.8 & 2100 & 63265 & 8933 & 1.48 & 59.3 & 1200 & 4332 \\
\hline Angola & 50.5 & 2515 & 51429 & 5348 & 0.04 & 50.4 & 21 & 7912 \\
\hline Tanzania & 36.7 & 4460 & 88200 & 3704 & 2.01 & 34.7 & 2562 & 4126 \\
\hline Zambia & 31.2 & 916 & 91440 & 6779 & 1.15 & 30.1 & 625 & 2851 \\
\hline DRC & 24.4 & 3256 & 17250 & 2250 & 0.50 & 14.1 & 465 & 2084 \\
\hline Botswana & 20.7 & 888 & 10217 & 5620 & 1.85 & 18.8 & 647 & 1378 \\
\hline Mozambique & 17.4 & 2593 & 30400 & 5685 & 4.00 & 13.4 & 500 & 1351 \\
\hline Zimbabwe & 14.3 & 2583 & 18338 & 8692 & 5.30 & 9.0 & 2400 & 444 \\
\hline Namibia & 12.8 & 2382 & 64808 & 5378 & 2.07 & 10.8 & 1262 & 1119 \\
\hline Swaziland & 7.5 & 301 & 3800 & 1064 & 3.90 & 3.6 & 710 & 8 \\
\hline Malawi & 6.3 & 789 & 14597 & 2773 & 0.40 & 5.9 & 75 & 88 \\
\hline Lesotho & 4.3 & 3 & 4955 & 887 & 0.00 & 4.3 & 0 & 16 \\
\hline
\end{tabular}


This view provides the first estimate of rail market share in SADC countries other than South Africa. The major objective for developing this view was to guide further research, i.e. given the sensitivity parameters of the estimation is a large enough opportunity observed?

The research conducted on SADC countries indicates that there is significant potential available for rail systems in this region. The results per country are summarised in Figure 4.

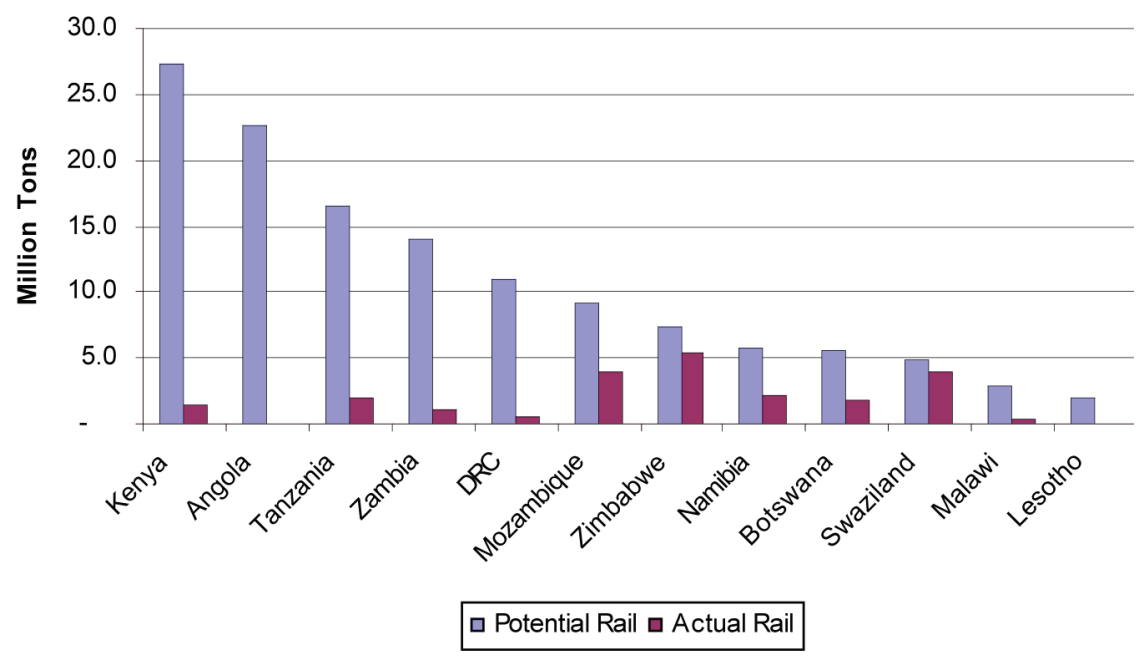

Figure 4: Actual and potential rail volumes (De Bod, 2008)

Transposing actual and potential rail volumes to Harris's curve shows that significant potential for cost reduction exists. Tons were converted into ton-km given the network length required for each flow in order to apply the density principle as developed by Harris (1977) (Figure 5).

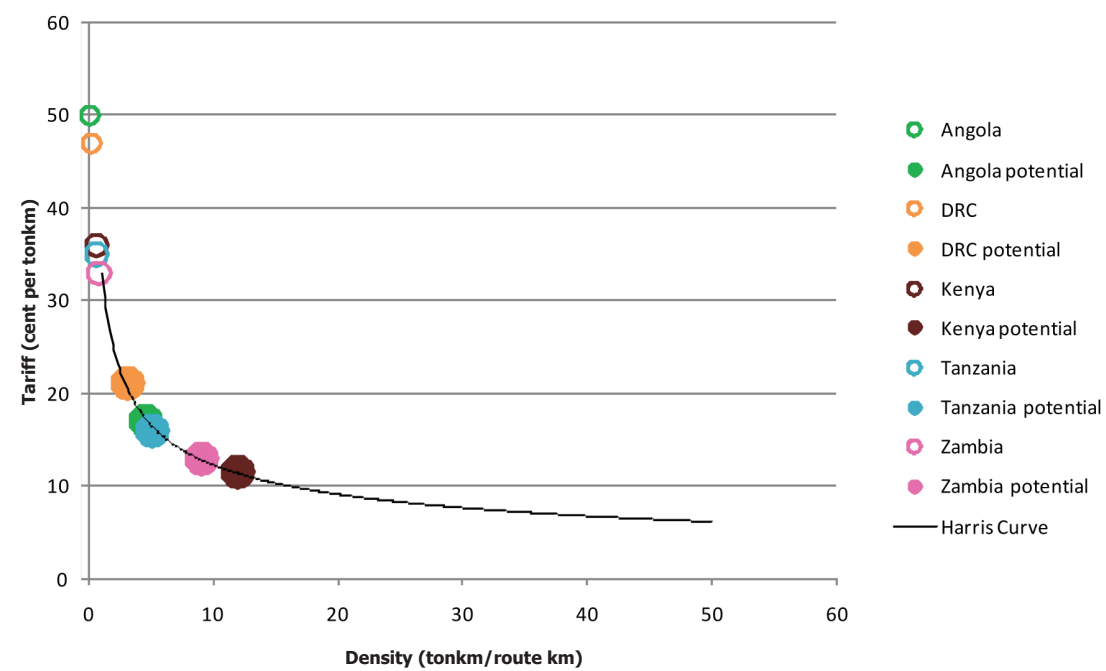

Figure 5: Harris's density curve for selected SADC countries 
The increase in density, however, goes hand-in-hand with upgrading rail infrastructure, and the potential for density should improve the business case for private investment in rail infrastructure. This is achievable because a reduction in the cost of transport (as indicated by moves down the Harris curve) serves three major SSA economic growth objectives. Businesses in general should become more competitive and railways can negotiate more profitable rates, i.e. if transport costs can be reduced by $30 \%$, the railway could charge $15 \%$ more and businesses would save $15 \%$ on transport costs. Lastly, the investment in infrastructure could, by itself, create induced economic growth. Density cost savings is possible due to lowering of fixed infrastructure charges per ton-km as indicated by the high fixed cost component of a railroad (Figure 6).

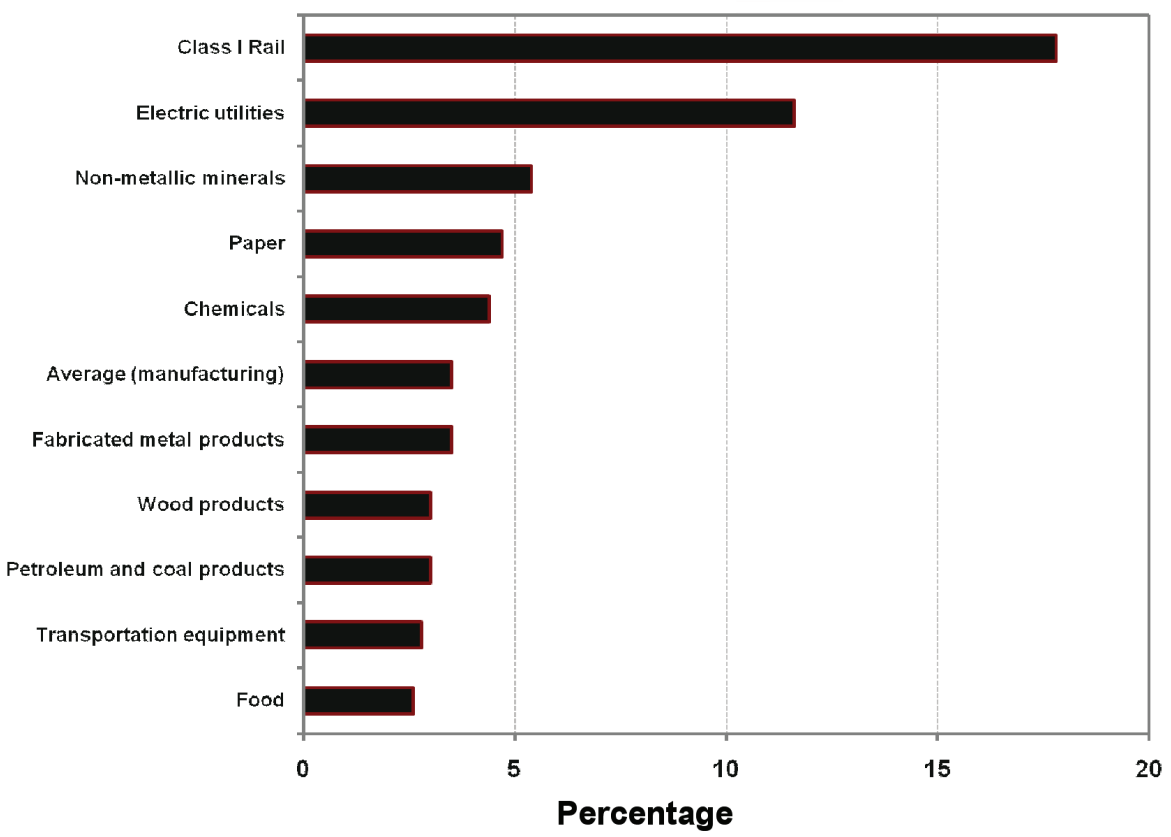

Figure 6: Capital expenditure as a percentage of revenue (Rodrique, 2009)

SSA governments are keen to relieve themselves of heavy expenditure on railways, which historically represented a drain on national budgets. The New Partnership for Africa's Development's (Nepad) intention is for the private sector to contribute towards building infrastructure, plug the funding gap and reverse the flow of public money towards railway operations. Furthermore Nepad has prioritised providing institutional support for the concessioning of railways (De Bod, 2008). Due to the quantum of finance required to finance railway infrastructure, government policy support is necessary. This support as well as policy direction from funding nations has been lacking up to now, but could and should induce this type of investment. 
The corridor concept, already the focal point for regional development initiatives (SADC, 2006), is ideally suited to taking advantage of this potential density. Initially based on making existing transport routes more efficient, corridors are critical to achieving the region's economic and political objectives. This becomes even more important because 15 of the continent's 53 states are landlocked and require efficient regional transport links for access to ports (De Bod, 2008). Furthermore, the transport distances for all these countries are long, over routes that can be densified, and therefore provide ideal opportunities for rail transport to save costs.

\section{CONCLUSION}

Regional and international trade are central to economic growth, and efficient transport is at the heart of competitive trade. Most SSA countries, individually, are too small to generate the economies of scale (and resulting competitiveness) found in larger markets. Over longer distances and with adequate density, rail is considerably more efficient than road. The research presented here confirms that the potential for densified rail transport is available.

As with most other initiatives in SSA, unlocking this potential will require efficient crosscountry collaboration. To this end, the simplification of the RECs is imperative in freeing resources for productive use. The responsibility of SSA governments, donors and investors to design solutions that will work for both people and situations in individual SSA countries is also critical. 


\section{REFERENCES}

Brautigam, D. 2010. Africa's Eastern Promise - What the West can learn from Chinese investment in Africa. Available from: http://www.foreignaffairs.com/articles/65916/deborahbrautigam/africa\%E2\%80\%99s-eastern-promise (accessed 20 May 2010).

Chowdhury, A. \& Garonna, P. 2007. Effective foreign aid, economic integration and subsidiarity: lessons from Europe. United Nations Economic Commission for Europe. Available from: http://www.unece.org/oes/disc_papers/ECE_DP_2007-2.pdf (accessed 21 May 2010).

Clendaniel, M. 2009. The Good 100: Dambisa Moyo - We love to take care of Africa. But does Africa need taking care of? Available from: http://www.good.is/post/the-good-100dambisa-moyo/ (accessed 19 May 2010).

CSIR \& Stellenbosch University. 2009. The 6th Annual State of Logistics Survey for South Africa. Available from: http://www.csir.co.za/sol/ (accessed 21 May 2010).

De Bod, A. 2008. South Africa's freight transport involvement options in Sub-Saharan Africa: Declining infrastructure and regulatory constraints. Unpublished master's thesis. Stellenbosch: Stellenbosch University.

Drew, J. 2006. Rail freight: the benefits and costs of vertical separation and open access. Association for European Transport and contributors 2006. Available from: www. etcproceedings.org/paper/download/1676 (accessed 22 September 2010).

Easterly, W. 2008. Can the West save Africa? NBER Working Paper No. 14363. Available from: http://www.nber.org/papers/w14363.pdf (accessed 11 May 2010).

Graham, D., Couto, A., Adeney, W. \& Glaister, S. 2003. Economies of scale and density in urban rail transport: Effects on productivity. Transportation Research Part E. Logistics and Transportation Review, 39(6): 443-58.

Harris, R. G. 1977. Economies of traffic density in the rail freight industry. The Bell Journal of Economics, 8(2): 556-64.

Havenga, J. H. 2007. The development and application of a freight transport flow model for South Africa. Unpublished doctoral thesis. Stellenbosch: Stellenbosch University.

Holmes, K.R., Feulner, E.J., \& O'Grady, M.A. 2008. 2008 Index of Economic Freedom. The Heritage Foundation, Washington D.C. and Dow Jones \& Company, Inc., New York. 
IMF. 2009. IMF positive about economic growth in sub-Saharan Africa. Available from: http://www.africagoodnews.com/economy/imf-positive-about-economic-growth-in-subsaharan-africa.html (accessed 19 May 2010).

Ivaldi, M. \& McCullough, G. J. 2001. Density and integration effects on Class I U.S. Freight Railroads. Journal of Regulatory Economics, 19(2): 161-82.

Joy, S. 1989. Railway costs and planning. Journal of Transport Economics and Policy, 23(1): 45-54.

Madavo, C. 2005. Africa: The development challenges of the 21st century. Paper presented at the Congressional Staff Forum on Africa Retreat, convened by the Woodrow Wilson International Center, March 8-10, 2005.

Mercer Management Consulting. 2002. Infrastructure separation and open access: Lessons from experience. Unpublished confidential report.

Moyo, D. 2009. Dead aid - Why aid is not working and how there is a better way for Africa. New York: Farrar, Straus and Giroux.

Ndulu, B., Kritzinger-van Niekerk, L. \& Reinikka, R. 2005. Infrastructure, regional integration and growth in sub-Saharan Africa. From: Africa in the world economy - the national, regional and international challenges. Fondad, The Hague, December 2005, www.fondad.org.

Njini, F. 2010. US $\$ 100$ bn needed for SADC projects. The Southern Times. 9 August 2010.

Ordover, J. \& Pittman, R. 1994. Restructuring the railway for competition. Paper delivered at the OECD/World Bank Conference on Competition and Regulation in Network Infrastructure Industries, Budapest: June 28-July 1, 1994.

Pietrantonio, L. D. \& Pelkmans, J. 2004. The economics of EU rail reform. Bruges European economic policy briefing. BEEP briefing no. 8. Brugge: College of Europe.

Pittman, R. 2007. Options for restructuring the state-owned monopoly railway. In Dennis, S. M. and Tally, W. K. (Eds). Research in transportation economics. Volume 20: Railroad Economics (pp. 179-98). Oxford: Elsevier.

Rodrigue, J. P. 2009. The geography of transport systems. Available at http://people.hofstra. edu/geotrans/eng/ch7en/conc7en/ch7c1en.html (accessed on 9 September, 2010). 
SADC. 2006. Corridors driving infrastructure development. Available from: http://www. sardc.net/editorial/sadctoday/view. asp?vol=352\&pubno=v9n1\&page=DEVELOPMEN T\%20CORRIDORS (accessed 19 May 2010).

Santiso, J. 2006. An introduction to the OECD Development Centre. Available from: www. oecd.org/dataoecd/15/34/37424335.ppt (accessed 21 May 2010).

Shleifer, A. 2009. Peter Bauer and the failure of foreign aid. Cato Journal, 29(3): 379-90.

Simuyemba, S. 2007. Linking Africa through regional infrastructure. Economic Research Papers, 2007(64). African Development Bank. Available from: http://www.afdb.org/ fileadmin/uploads/afdb/Documents/Publications/00157662-EN-ERP-64.PDF (accessed 21 May 2010).

Taylor, I. 2006. Challenges facing the Commonwealth and Millennium Development Goals in Africa. Paper prepared for the Round Table meeting 'The Commonwealth after Valetta' held in Windsor, England.

UNECA. 2007. Economic Report on Africa 2007: Accelerating Africa's development through diversification. Part 1: Recent Economic Trends and Prospects for 2007. Available at: http://www.uneca.org/eca_resources/Publications/books/era2007/chap1.pdf (accessed 18 September 2010).

World Bank. 2005. Meeting the challenges of Africa's development: A World Bank Group Action Plan. Available from: http://siteresources.worldbank.org/INTAFRICA/Resources/ aap_final.pdf (accessed 21 May 2010).

World Bank. 2006. Review of selected railway concessions in sub-Saharan Africa. http://www4. worldbank.org/afr/ssatp/Resources/WorldBank-WorkingPapers/ESW-RailwayConcessions. pdf (accessed 22 September 2010.)

Table of acronyms and abbreviations

\begin{tabular}{|l|l|}
\hline IMF & International Monetary Fund \\
\hline Nepad & New Partnership for Africa's Developments \\
\hline OECD & Organisation for Economic Co-operation and Development \\
\hline REC & Regional Economic Communities \\
\hline SADC & Southern African Development Community \\
\hline SSA & Sub-Saharan Africa \\
\hline
\end{tabular}

